\title{
Use of methylphenidate by university students in the health area
}

\author{
Uso de metilfenidato por estudantes da área de saúde \\ Uso de metilfenidato por estudiantes universitarios en el área de salud
}

Received: 06/24/2021 | Reviewed: 07/04/2021 | Accept: 07/05/2021 | Published: 07/16/2021

Ana Carolina Zuca Pedreira de Freitas

ORCID: https://orcid.org/0000-0003-1324-0313 Universidade Salvador, Brazil

E-mail: carollzzuca@gmail.com

Saiane Menezes Moreira

ORCID: https://orcid.org/0000-0001-9781-4112 Universidade Salvador, Brazil

E-mail: saianemenezes@gmail.com

Lisandra Maria Lago

ORCID: https://orcid.org/0000-0003-4319-0732

Universidade Salvador, Brazil

E-mail: lisandra_lago@icloud.com

Laís Nery Pinheiro

ORCID: https://orcid.org/0000-0001-9947-0819

Universidade Federal da Bahia, Brazil

E-mail: lais-nery@hotmail.com

Danielle Stefane Pinto da Silva

ORCID: https://orcid.org/0000-0003-2899-7466 Universidade Salvador, Brazil

E-mail: daniellepinto10@hotmail.com

Mariane Coutinho Araújo

ORCID: https://orcid.org/0000-0001-5125-9926 Universidade Salvador, Brazil

E-mail: mariane_coutinho1999@hotmail.com

Laís Campos de Oliveira

ORCID: https://orcid.org/0000-0002-5327-7922 Universidade Salvador, Brazil

E-mail: 1.camposoliveiraa@gmail.com

Joseanne Barbosa Costa

ORCID: https://orcid.org/0000-0002-0961-3802 Universidade Salvador, Brazil

E-mail: josy.barbosacosta@gmail.com

Vanessa Tigre Almeida Chaves

ORCID: https://orcid.org/0000-0003-2177-119X

Universidade Estadual de Feira de Santana, Brasil E-mail: t.nessa@hotmail.com

Anny Carolinny Tigre Almeida Chaves ORCID: https://orcid.org/0000-0002-9290-7368 Universidade Salvador, Brazil E-mail: annytigre@hotmail.com

\begin{abstract}
Methylphenidate is the drug most frequently used in the treatment of attention deficit hyperactivity disorder. However, due to its psychostimulant properties, this substance has been used to stimulate productivity and increase intellectual capacity in several areas of study. In this work, the characteristics of the use of methylphenidate among pharmacy, nursing, and medical students of a university in the capital of Bahia were analyzed. In this cross-sectional study, 338 students from different semesters of the aforementioned courses were interviewed. The instrument used for data collection was a standardized self-completed questionnaire applied by the researchers. Altogether, $76 \%$ of respondents were female and the average age was 22 years old. The frequency of students who used or who had already used methylphenidate at some point in their academic life was higher among medical students (12\%). The main justification for the use of this substance was the higher concentration to study (59\%). Also, 92\% of respondents claimed to use Methylphenidate without medical supervision and $80 \%$ indicated the time of the tests as the time of greatest use of this drug. These results show high non-prescribed use of methylphenidate among health care students.
\end{abstract}

Keywords: Methylphenidate; College students; Psychoactive substances. 


\begin{abstract}
Resumo
O metilfenidato é o medicamento mais frequentemente utilizado no tratamento do transtorno do déficit de atenção e hiperatividade. No entanto, devido as suas propriedades psicoestimulantes, essa substância tem sido utilizada com o objetivo de estimular a produtividade e aumentar a capacidade intelectual em diversas áreas do estudo. Neste trabalho foram analisadas as características de uso do metilfenidato entre os estudantes de farmácia, enfermagem e medicina de uma universidade da capital baiana. Neste estudo transversal, foram entrevistados 338 estudantes de diferentes dos cursos supracitados. O instrumento utilizado para coleta de dados foi um questionário padronizado e de autopreenchimento aplicado pelas pesquisadoras. Ao todo, $76 \%$ dos entrevistados foram do sexo feminino e a média de idade foi de 22 anos. A frequência de alunos que fazia ou que já haviam feito uso do metilfenidato em algum momento da vida acadêmica foi maior entre os estudantes de medicina (12\%). A principal justificativa para o uso dessa substância foi a concentração para estudar (59\%). Além disso, 92\% dos entrevistados que consumiram o medicamento, afirmaram fazer uso do metilfenidato sem acompanhamento médico e $80 \%$ apontaram a época das provas como o momento de maior utilização desse medicamento. Estes resultados evidenciam o elevado uso nãoprescrito do metilfenidato entre estudantes da área de saúde.
\end{abstract}

Palavras-chave: Metilfenidato; Universitários; Substâncias psicoativas.

\title{
Resumen
}

El metilfenidato es el fármaco más utilizado em el tratamento del transtorno por déficit de atención com hipersactividad. Sin embargo, debido a sus propriedades psicoestimulantes, esta sustância se há utilizado com el objetivo de estimular la productividad y aumentar la capacidade intelectual em varias áreas de estúdio. Em este trabajo se analizaron las características del uso de metilfenidato entre estudiantes de farmácia, enfermeira y medicina de uma universidad de la capital bahiana. Em este estúdio transversal se entrevistó a 338 estudiantes de diferentes semestres de los cursos antes mencionados. El instrumento utilizado para la recolección de datos fue um cuestionario autocompletado aplicado por investigadores. Em total, el $76 \%$ de los encuestados eran mujeres y la edad promedio era de 22 años. La frecuencia de estudiantes que tomaron o que ya habían usado metilfenidato em algún momnto de su vida académica fue mayor entre los estudiantes de medicina (12\%). La principal justificación del uso de esta sustancia fue la mayor concentración a estudiar (59\%). Además, el 92\% de los encuestados afirmo usar metilfenidato sin supervisión médica y el $80 \%$ indicó el momento de las pruebas como el momento de mayor uso de este fármaco. Estos resultados muestran um alto uso no prescrito de metilfenidato entre los estudiantes de atención médica.

Palabras clave: Metilfenidato; Estudiantes universitários; Sustancias psicoativas.

\section{Introduction}

Nowadays, some psychotropic substances, modifying the ways of being, living, and working, are only secondarily used to minimize suffering and, in many cases, to enhance student performance (Brant \& Carvalho, 2012).

Called pharmacological cognitive enhancement, the idea of using legally prescribed or over-the-counter drugs to "turbine the brain" has become an alternative to improve brain capacity in school performance. The purpose of using these drugs is the possibility of altering the brain process, aiming to improve memory, mood, and attention in healthy people (Barros; Ortega, 2011).

Methylphenidate hydrochloride is one of the most consumed drugs to stimulate productivity. This is part of the group of amphetamines (such as cocaine), which is commonly sold under the names Concreta, Ritalin, and Ritalin LA (Coli, Silva \& Nakasu, 2016).

Methylphenidate is a psychostimulant and its use is legally authorized for the treatment of children diagnosed with Attention Deficit Hyperactivity Disorder (ADHD). When consumed in the dosage prescribed by a doctor, its use helps in the performance of the school and academic activities, increasing the capacity of executive functions, increasing concentration, and minimizing the effects of fatigue (Itaborahy, 2009).

Despite the aforementioned indication, three "non-medical" uses of this drug are known: recreational, to increase vigilance and availability during leisure; aesthetic, to help with weight loss; and cognitive, to improve professional and academic cognitive performance (Barros; Ortega, 2011).

However, the university is a space where, quite frequently, the use of these drugs in an exacerbated way occurs, as it is an environment that encourages research, learning and that requires a high degree of dedication from students. Under these 
conditions, healthy university students have been using psychoactive substances, without prescription or medical supervision to enhance mental activities, aiming to optimize academic efficiency (Finger; Silva; Falavigna, 2013).

Methylphenidate is a black stripe drug and is included in the set of controlled drugs, so may have serious side effects (Gray, 2007). Therefore, it is essential to expand scientific studies and disseminate their results regarding the risks and adverse effects due to the indiscriminate use of methylphenidate by university students, also because the use of this substance, without medical supervision, can bring irreparable harm to health.

Thus, this study aims to identify the prevalence of the use of methylphenidate by university students in the health area and the main risks and side effects due to the use of methylphenidate by them without specialist supervision.

\section{Methodology}

This is a descriptive cross-sectional study, with questionnaires applied to the pharmacy, medicine, and nursing students at a university in the capital of Bahia.

The sample was defined by calculating the Sample Error Estimate for a finite population of 2536 enrolled students, distributed in the semesters of the aforementioned courses. Thus, assuming a sampling error of 5\%, the confidence level of $95 \%$, and through the formula $n=Z^{2}$.P.Q.N $/ \mathrm{e}^{2}$. (N-1)+Z2.Q.P, we defined that the required sample size (n) was at least 338 individuals. In this formula, we consider that $\mathrm{n}$ is the required sample size, " $\mathrm{Z}$ " is the confidence level, "P" is the expected amount of hit (\%), $\mathrm{Q}$ is the expected amount of error (\%), $\mathrm{N}$ is the total population and finally, $\mathrm{e}$ is the level of accuracy.

Thus, 338 were applied questionnaires, respecting the minimum number of students interviewed. The inclusion criteria used were being a pharmacy, medicine, or nursing student and being over 18 years old. Therefore, we used a semistructured data collection instrument, consisting of questions that allowed the assessment of the sociodemographic profile (gender, age group, marital status, monthly income) in the students from nursing, pharmacy, and medicine courses. Participants were informed about the research, its importance, and objectives and after signing the Informed Consent Form (ICF), they answered the questionnaire. The researchers read the questions to the students to guarantee the absence of misinterpretation.

This research complies with the norms of Resolution $\mathrm{n}^{\circ}$ 466, of December 12, 2012, and was approved by the Research Ethics Committee of Universidade Salvador, under opinion $\mathrm{n}^{\circ}$ 4.232.241.

For data tabulation and analysis, we used the GraphPad Prisma program (5.0), with a significance level of 5\%. Descriptive data statistics interpreted the answers to the questionnaires and Pearson's correlation related to the variables and knowledge acquired in the analyzed courses.

\section{Results and Discussion}

From the analysis of the student's profile, we could detect that $40 \%$ of respondents $(n=136)$ are from the pharmacy course, $30 \%(\mathrm{n}=101)$ from the medicine course, and 30\% $(\mathrm{n}=101)$ from the nursing course. Of these, $76 \%$ are woman $(\mathrm{n}=258)$ and $83 \%(\mathrm{n}=278)$ are under 25 years old, as shown in Table 1. 
Table 1. Distribution of students, by course, included in the study according to gender and age.

\begin{tabular}{|c|c|c|}
\hline Course & Sex & Age \\
\hline Pharmacy $-40 \% \quad(n=136)$ & $\begin{array}{c}\text { Men }-26 \%(n=36) \\
\text { Women }-74 \%(n=100)\end{array}$ & $\begin{array}{l}\text { Below } 25 \text { anos }-77 \%(n=107) \\
\text { Above } 25 \text { anos }-23 \%(n=29)\end{array}$ \\
\hline Medical $-30 \%(n=101)$ & $\begin{array}{c}\text { Men }-29 \%(\mathrm{n}=29) \\
\text { Women }-71 \%(\mathrm{n}=72)\end{array}$ & $\begin{array}{c}\text { Below } 25 \text { anos }-91 \%(n=92) \\
\text { Above } 25 \text { anos }-9 \%(n=9)\end{array}$ \\
\hline Nursing $-30 \%(n=101)$ & $\begin{array}{c}\text { Men }-15 \%(\mathrm{n}=15) \\
\text { Women }-85 \%(\mathrm{n}=86)\end{array}$ & $\begin{array}{l}\text { Below } 25 \text { anos }-78 \%(n=79) \\
\text { Above } 25 \text { anos }-22 \%(n=22)\end{array}$ \\
\hline
\end{tabular}

Source: Authors.

A survey conducted by Micoulaud and Macgregor (2014) to show the early use of methylphenidate showed results similar to those of this research. These authors detected a prevalence of $76 \%$ of females and a prevalent age group of approximately 22 years old. On the other hand, Habibzadeh (2011) in an Iranian survey found a mean age similar to the aforementioned studies (21.4 years old), however, with a predominance of males.

The students in this study were divided between the 10 semesters of the 03 courses above, with a predominance (75.7\%) among the first 5 semesters, as shown in Table 2.

Table 2. Distribution of student semesters.

\begin{tabular}{c|c}
\hline Semester & Students \\
\hline $1^{\circ}$ & $24.3 \%(\mathrm{n}=82)$ \\
\hline $2^{\circ}$ & $12.4 \%(\mathrm{n}=42)$ \\
\hline $3^{\circ}$ & $13.3 \%(\mathrm{n}=45)$ \\
\hline $4^{\circ}$ & $13.6 \%(\mathrm{n}=46)$ \\
\hline $5^{\circ}$ & $12.1 \%(\mathrm{n}=41)$ \\
\hline $6^{\circ}$ & $3.6 \%(\mathrm{n}=12)$ \\
\hline $7^{\circ}$ & $17.2 \%(\mathrm{n}=58)$ \\
\hline $8^{\circ}$ & $1.8 \%(\mathrm{n}=6)$ \\
\hline $9^{\circ}$ & $1.5 \%(\mathrm{n}=5)$ \\
\hline $10^{\circ}$ & $0.3 \%(\mathrm{n}=1)$ \\
\hline
\end{tabular}

Source: Authors.

Regarding the possibility of work overloading their activities as a student, $47 \%$ of respondents considered that both activities, if carried out simultaneously, would reduce the level of attention in the studies. A work carried out by Silva et al. (2011) with nursing students from a private college in the interior of São Paulo showed that $50 \%$ of respondents had an employment relationship. They considered that working and studying entailed an excessive workload of activities, which overloaded their routines and having to deprive them of leisure time to fulfill all the tasks.

When asked about the amount of sleep, the vast majority of students (83\%) answered that they sleep, on average, between 4 and 8 hours a day. In addition, 53\% of students rated sleep quality as good, and 31\% considered it poor.

In research carried out by Castilho et al. (2015), the vast majority of respondents slept, on average, between 4 and 8 hours a day. In addition, $56.7 \%$ of these individuals stated that their sleep quality was good and another $28.8 \%$ classified it as 
poor. In this work, we also observed that the lesser amount of sleep and the poor quality of sleep were considered the main factors for the alteration in the academic performance of the respondents. According to Pereira et al (2015), students during class time should sleep an average of 8 hours a day to perform their academic activities well.

Another important data analyzed was the level of stress in the studies. Thus, 58\% of students considered their stress levels moderate in their studies and $41 \%$ considered it high. Furthermore, $22 \%$ stated that the concentration for such activity is bad and $63 \%$ reported it to be good.

A study by Pereira, Miranda, and Passos (2010) with nursing students found that $81 \%$ of individuals considered stressed with academic activities. Chaves et al. (2016) conducted a study with first-year students at the Centro Universitário Herminio Ometto in São Paulo and observed that 57\% of university students already had symptoms of stress. Furthermore, Cestari et al. (2017) in research carried out with nursing students found that $64 \%$ of students were stressed about their studies.

According to Gervásio (2012), such stress levels are linked to some factors, including responsibilities with academic activities, work, care for the home and family, among others. Bublitz et al. (2012), while conducting a survey with students from the $5^{\text {th }}$ and $6^{\text {th }}$ semesters of the nursing course at the State University of Rio de Janeiro (UERJ) identified as the main signs and symptoms of stress experienced by such students, the fact of not sleeping enough, the unwillingness to academic practices, emotional tension, and fatigue.

Stress symptoms may reflect the early use of psychostimulants to enhance cognitive abilities and meet the aforementioned physiological needs (Silva et al., 2012; Carvalho et al., 2014 apud Alberto et al., 2017).

As for the need to use some substance or stimulant compound to improve the performance of academic activities, $9 \%$ answered that they always use some psychostimulant and 23\% reported that they sometimes feel the need to use some stimulant compound. Psychostimulants have goals that permeate increased alertness and motivation, minimizing the need for rest, in addition to showing improvement in mood and cognitive behavior and antidepressant properties. The main substances used for these purposes are caffeine, methylphenidate, modafinil, piracetam, energy drinks, and amphetamines (Morgan et al., 2017).

A survey conducted by Castilho et al. (2015) pointed out that $4.1 \%$ of respondents used some psychostimulant and, among these, $60 \%$ reported using methylphenidate. Therefore, when asked if they use or have used Methylphenidate, $7 \%$ $(n=25)$ of the students interviewed in this research said yes, being $12 \%(n=12)$ medical students, $4 \%(n=6)$ pharmacy students, and $7 \%(\mathrm{n}=7)$ nursing university students.

Methylphenidate is the most consumed psychoactive substance in the world and also the most used for recreational use. Brazil is the second country with the highest consumption rate, behind only the United States. In an analysis carried out by the National Controlled Products Management System (SNGPC), in 2012, there was a considerable increase in the consumption of this substance, with an increase of $28.2 \%$ of products sold more than in 2009 (Brasil, 2012; Cutler, 2014; Decotelli; Bohrer; Bicalho, 2013 apud Cordeiro \& Pinto, 2017).

According to Finger et al. apud Silveira et al. (2015), the most used drug among medical students is methylphenidate hydrochloride. This stimulates the central nervous system and its mechanism of action consists of blocking dopamine reuptake, releasing dopamine and norepinephrine into the synaptic cleft. According to Silva (2010), this psychostimulant can benefit some brain functions; however, when excessively consumed, they cause adverse results to those expected, and may even cause seizures.

Also, this psychostimulant is one of the drugs with the highest prescription rate in the world, being used in many countries for the pharmacological treatment of ADHD and some specific cases of depressive disorder and fatigue. When prescribed with appropriate doses, the chances of this substance leading to addiction are very small, therefore, it is safe with a good level regarding side effects (Cesar et al., 2012). 
The data presented in this research is similar to the study carried out by Cruz et al. (2011), which pointed out that $8.6 \%$ of the medical students at the Federal University of Bahia (UFBA) analyzed had already made or used Methylphenidate. In a survey carried out by these researchers at UFBA, the illegal sale of methylphenidate hydrochloride was highlighted, without the need for a medical prescription. This research also addressed the level of knowledge of university students regarding the abusive and indiscriminate use of the drug, demonstrating the practice of purchasing medication, especially psychoactive drugs, without prescription and proper professional guidance. However, research carried out in different cities in Brazil with medical students, by Pires et al (2018), Silva Junior et al. (2016), and Lage et al. (2015), showed that the use of methylphenidate was even greater, being $29 \%, 23 \%$, and $28.4 \%$, respectively.

These results show that the non-therapeutic use of methylphenidate is a common practice by Brazilian university students, mainly by medical students, and the main objectives indicated by them to justify the use of these substances were the improvement of alertness and the increased concentration for academic activities (Maier et al., 2013; Wilens et al., 2008 apud Cordeiro and Pinto, 2017).

Studies carried out in some countries such as South Africa, the United Kingdom, Brazil, Switzerland, and the United States were concerned about the large increase in the consumption of over-the-counter psychostimulants by academics (Lage et al, 2015; Singh et al., 2014; Beyer et al., 2014; Maier et al., 2013; Hall et al., 2005; Barret et al., 2005 apud Silva Júnior et al., 2016).

Another survey carried out in this area, in France, showed that out of 206 respondents, 139 (67.4\%) had consumed at least one psychoactive substance in the last 12 months. In the United Kingdom and Ireland, 877 university students participated in an online questionnaire and approximately 9.4\% claimed to have used some medication for cognitive improvements (Franchi et al., 2014; Singh; Bard; Jackson, 2014 apud Cordeiro \& Pinto, 2017). In Switzerland, 13.8\% of students stated that they used psychostimulants without professional supervision at least once in their lives. In the United States, studies show that the use of psychostimulants without a medical prescription is 35\% among university students (Maier et al., 2013; Wilens et al., 2008 apud Cordeiro, \& Pinto, 2017).

The use of methylphenidate without a medical prescription is worrisome, as prescription A (yellow color) is required, which is difficult to access, even for prescribing professionals (Cruz et al., 2013).

The use of this substance without a medical prescription by academics, mainly in the health area, has been a reason for research and fear due to its cardiovascular effects and the risk of dependence. Some studies have shown that at the university level, the prevalence of healthy students who use methylphenidate or have already used it for academic improvement ranges from 3 to 35.5\% (Low \& Gendaszek, 2002; Teter et al., 2003; Barret et al., 2005; Desantis et al., 2008; Dupont et al., 2008; Wilens et al., 2008; Habibzadeh et al., 2011; Herman et al., 2011 apud Silva Junior et al., 2016).

In this study, $92 \%$ of the population who claimed to use this stimulant responded that they used this drug without a prescription, and more than half (52\%) of the students reported that they used this substance on their own, while $35 \%$ stated that it was an indication from friends and $9 \%$ from a pharmacist.

Coli, Silva, and Nakasu (2016) presented as expressive results, in a research with medical students from the Faculdade do Sul de Minas, that $46.67 \%$ of the indications for the consumption of Methylphenidate were through friends and $26.67 \%$ by colleagues from college.

Also, $80 \%$ of the students who claimed to use methylphenidate reported that they use this drug at exam times. Studies carried out by Pires et al (2018) and Silva Júnior (2016) showed results similar to those pointed out in this research, when $88.1 \%$ and $78.3 \%$, respectively, of respondents, reported that they used Methylphenidate on the eve of tests.

These results show that when people are in a state of high anxiety, as in the time of university exams, they present greater emotional vulnerability. According to Carmo and Simionato (2012), this occurs under unpleasant physiological 
reactions, tense posture, tired facial expression, headaches, stomach disorders, and changes in physiological, behavioral, and cognitive components.

The students in this research stated that the factors that led them to use methylphenidate were the highest concentration to study (59\%) and the longest waking time to carry out this practice (27\%). Similar results were observed in the work of Pasquini (2013), in which $84.21 \%$ of students confirmed the desire to increase concentration to study. In the studies by Carneiro et al (2013), Sebastian and Alfonso (2014), and Silva Júnior et al. (2016), 54.05\%, 71.3\%, and 63.8\% of students respectively reported having an improvement in academic performance, mainly due to improved concentration.

In this study, students also reported that they experienced one or more side effects after using methylphenidates, such as insomnia, decreased appetite, anxiety, nausea, euphoria, abdominal pain, dizziness, and lack of interest. In other studies, the main effects observed were tachycardia, palpitation, loss of appetite, anxiety, tremors, and dry mouth (Carneiro et al., 2013; Silva Júnior et al., 2016).

The indiscriminate use of this psychostimulant can lead to numerous risks, compromising the users' physical and mental health. Individuals who use Methylphenidate tend to believe that this substance will enhance the level of studies; however, if the individual does not have any type of pathology that generates attention deficit, the effects can be adverse, such as anorexia, insomnia, headache, arrhythmia, and dependence (Carneiro et al., 2013).

\section{Final Considerations}

Through this work, we could observe that Methylphenidate is a central nervous system stimulant that has been used, without a medical prescription, by healthy individuals who aim to improve their performance in academic activities. Its use without medical supervision is not recommended because it is a black stripe drug, which can pose serious health risks.

We found that the non-prescribed use of Methylphenidate by Brazilian university students in the health area is a reality and requires care by health professionals to face it, including through socio-educational techniques to raise awareness of these students in the sense of using psychostimulants only with medical indication.

The justifications for the use of methylphenidates, such as increasing concentration for studies and being able to spend more time awake aiming at better results in the course of academic activities, raise the importance of new studies on this psychostimulant, aiming to increasingly spread the concept of this drug and its function.

\section{References}

Alberto, M. S. I. Uso de metilfenidato entre acadêmicos no interior de Rondônia. $2017 . \quad$ http://periodicos.unincor.br/index.php/r evistaunincor/article/view/2963/pdf_623.

Barrett, S. P., Darredeau, C, Bordy, L. E, \& Pihl, R. O. Characteristics of methylphenidate misuse in a university student sample. Canadian Journal of Psychiatry, 50, 457

Brant, L. C., \& Carvalho, T. R. F. Metilfenidato: medicamento gadget da contemporaneidade. Interface (Botucatu), 16, 623-636

Barros, D., \& Ortega, F. Metilfenidato e aprimoramento cognitivo farmacológico: representações sociais de universitários. Saude soc., 20, 350-362

Bublitz, S, Guido, L. A, Freitas, E. O, \& Lopes, L. F. D. Estresse em estudantes de enfermagem: uma revisão integrativa. Revista de Enfermagem da UFSM, 2 https://periodicos.ufsm.br/index.php/reufsm/article/view/3485.

Carneiro, S. G, Prado, A. S. T., \& Moura, H.C. O uso não prescrito de metilfenidato entre acadêmicos de Medicina. Cadernos UniFOA, 53-9

Coli, A. C. M., Silva, M. P. de S., \& Nakasu, M. V. P. Uso não Prescrito de Metilfenidato entre Estudantes de uma Faculdade de Medicina do Sul de Minas Gerais. Revista Ciências em Saúde 6,

Carmo, J. S., \& Simionato, A. M. Reversão de ansiedade à matemática: alguns dados da literatura. 2012. http://www.scielo.br/pdf/pe/v17n2/v17n2a14.pdf.

Cestari, V. R. F. et al. Estresse em estudantes de enfermagem: estudo sobre vulnerabilidades sociodemográficas e acadêmicas. 2017. http://www.scielo.br/ pdf/ape/v30n2/1982-0194-ape-30-02-0190.pdf. 
Castilho, C. P. A privação de sono nos alunos da área de saúde em atendimento nas Unidades Básicas de Saúde e suas consequências. 2015. http://www.revistas.usp.br/revistadc/article/view/106795.

Cesar, E. L. R, et al. Artigo original Uso prescrito de cloridrato de metilfenidato e correlatos entre estudantes universitários brasileiros Prescribed use of methylphenidate hydrochloride and its correlates among Brazilian college students. https://www.scielo.br/j/rpc/a/v8dC6MgWHhrhgpzQzTVfDK w/?lang=pt\&format=pdf.

Chaves, L. B. et al. Estresse em universitários: análise sanguínea e qualidade de vida. 2016. http://pepsic.bvsalud.org/scielo.php?script=sci_arttext\&pid=S $1808-56872016000100004$.

Castilho, C. P. A privação de sono nos alunos da área de saúde em atendimento nas Unidades Básicas de Saúde e suas consequências. 2015. http://www.revistas.usp.br/revistadc/article/view/106795.

Cordeiro, N., \& Pinto, R. M. C. Consumo de estimulantes cerebrais em acadêmicos da área da saúde na cidade de Ponta Grossa-PR. 2017. https://revistas.ufpr.br/academica/article/view/53234/32986.

Cruz, T. C. S. C., Barreto Junior, E. P. S., Gama, M. L. M., Maia, L. C. M., et al. Uso não prescrito de metilfenidato entre estudantes de Medicina da UFBA. Gaz. méd. Bahia, 81, 3-6

Carneiro, N. B. R, et al. Perfil de uso de metilfenidato e correlatos entre estudantes de medicina. Revista Eletrônica Acervo Saúde.

Desantis, A. D., Webb, E. M, \& Noar, S. M. Illicit use of prescription ADHD medications on a college campus: a multimethodological approach. Journal of American college health, 57, 315-324

Dupont, R. L, et al. Characteristics and motives of college students who engage in nonmedical use methylphenidate. Am J Addict, 17, 167-171

Finger, G., Silva, E. R., \& Falavigna, A. Use of methylphenidate among medical students: a systematic review. Rev. Assoc. Med. Bras., 59, 285-289

Factors. Pharmacotherapy: The Journal Of Human Pharmacology And Drug Therapy, 23, 609-617

Gray, J. D, Punsoni,M, Tabori, N.E, Melton, J.T. Methylphenidate Administration to Juvenile Rats Alters Brain Areas Involved in Cognition,Motivated Behaviors, Appetite, and Stress. J. Neurosci., 27, .7196-7207

Gervásio, S. M, et al. Análise do estresse em acadêmicos de Enfermagem frente ao primeiro estágio da grade curricular. J Health Sci Inst. 30(4):331-5.

Habibzadeh, A, Mahasti, M.A., Maghbooli, L. Shoja, M. M., et al. Illicit methylphenidate use among Iranian medical students: prevalence and knowledge. Drug Des Devel Ther, 5, 71-6, 2011.

Herman, L, Shtayermman, O, Aksnes, B, Anzalone, M. et al. The use of prescription stimulants to enhance academic performance among college students in health care programs. The Journal of Physician Assistant Education, 22, 15-22, 2011.

Itaborahy, C., Ortega, F. O metilfenidato no Brasil: uma década de publicações. http://www.scielo.br/scielo.php?pid=S1413$81232013000300026 \&$ script=sci_abstract\&tlng=pt.

Lage, D. C, Gonçalves, D. F, Gonçalves, G. O, Ruback, O. R, et al. Uso de metilfenidato pela população acadêmica: revisão de literatura. https://www.mastereditora.com.br/periodico/20150501_173303.pdf.

Use of psychostimulants among college students: a preliminary study. Psychology, Health \& Medicine, 7, 283-287

Maier, L. J, Liechti, M., Herzig, F, Schaub, M. P. To dope or not to dope: neuroenhancement with prescription drugs and drugs of abuse among Swiss university students. PLoS One, 8, e77967

Micoulaud-Franchi, J. A., Macgregor, A., \& Fond, G. A preliminary study on cognitive enhancer consumption behaviors and motives of French Medicine and Pharmacology students. Eur Rev Med Pharmacol Sci, 18, 1875-78

Morgan, H. L, Petri, A. F, Licks, P. A. K, Ballester, A. O, et al. Consumo de Estimulantes Cerebrais por Estudantes de Medicina de uma Universidade do Extremo Sul do Brasil: Prevalência, Motivação e Efeitos Percebidos. Rev. bras. educ. med., 41, 102-109

Pasquini, N. C. Uso de metilfenido (mfd) por estudantes universitários com intuito de "turbinar" o cerebro. 2013. https://docplayer.com.br/7800880-Uso-demetilfenido-mfd-por-estudantes-universitarios-com-intuito-de-turbinar-o-cerebro-nilton-cesar-pasquini-1.html.

Pereira, E. F. Barbosa, D. G. Andrade, R. D Claumann, G. D. Sono e adolescência: quantas horas os adolescentes precisam dormir?https://www.researchgate.net/profile/Rubian_Andrade2/publication/277899669_Sono_e_adolescencia_quantas_horas_os_adolescentes_precisam_dor mir/links/564de23008aeafc2aab07187.pdf.

Pereira, C. A. Miranda, L. C. S. Passos, J. P. O estresse e seus fatores determinantes na concepção dos graduados de enfermagem. 2010. http://reme.org.br/artigo/detalhes/107.

Pires, M. S, et al. O uso de substâncias psicoestimulantes sem prescrição médica por estudantes universitários. 2018. http://revista.fagoc.br/index.php/saude/article/view/370.

Sebastian, E. G. R., \& Alonso, R. C. D. Prevalencia de consumo de sustancias psicoestimulantes y factores asociados, para aumentar el rendimiento académico, en estudiantes de primero a decimo nivel de la facultad de medicina de la pontificia universidad católica del ecuador desde noviembre de 2013 a enero de 2014. 2014. http://repositorio.puce.edu.ec/bitstream/handle/22000/7336/11.27.001623.pdf?sequence=4\&isAllowed=y.

Silva, A. C. P., et al. A Explosão do Consumo de Ritalina. Revista de Psicologia da UNESP, 11 
Research, Society and Development, v. 10, n. 8, e45310817540, 2021

(CC BY 4.0) | ISSN 2525-3409 | DOI: http://dx.doi.org/10.33448/rsd-v10i8.17540

Silveira, V. I, et al. Uso de psicoestimulantes por acadêmicos de medicina de uma Universidade do Sul de Minas Gerais. 2015. http://periodicos.unincor.br/index.php/revistaunincor/article/view/2391/pdf_369.

Silva, P. Farmacologia. (8a ed.), Guanabara Koogan

Silva Júnior, D. S. Prevalência do uso de metilfenidato entre acadêmicos de medicina do centro universitário UNIRG - Tocantins. 2016. http://ojs.unirg.edu.br/index.php/1/article/view/1262.

Teter, C. J., Mccabe, S. E, Boyd, C. J., Guthrie, et al. Illicit methylphenidate use in an undergraduate student sample: prevalence and risk. 2003.

Wilens, T. E., Adler, L, A., Adams, J, Sgambati, S, et al. Misuse and diversion of stimulants prescribed for ADHD: a systematic review of the literature. Journal of the American Academy of Child \& Adolescent Psychiatry, 47, n21-31, 2008. 